\title{
IfIISGUC.ORG
}

"IST, GÜC̣" ENDÜSTRi iLișKiLERi VE inSAN KAYNAKLARI DERGiSi

"IS, GUC" INDUSTRIAL RELATIONS AND HUMAN RESOURCES JOURNAL

\section{Küreselleşme ve Makro-Kurumsal Teori: Bir Literatür Taraması}

\author{
Globalisation and Macro-Institutional Theory: \\ A Literature Survey
}

\author{
Ali FIKIRKOCA \\ Yrd.Doç.Dr., Ankara Üniversitesi SBF, İşletme Bölümü \\ R. Arzu KALEMCi \\ Çankaya Üniversitesi, İibf, İktisat Bölümü
}

Nisan/April 2011, Cilt/Vol: 13, Sayı/Num: 2, Page: 177-198

ISSN: 1303-2860, DOI: 10.4026/1303-2860.2010.0179.x

Makalenin on-line kopyasına erişmek için:

$\mathrm{http}: / /$ www.isguc.org/?p=article\&id=462\&vol=13\&num=2\&year=2011

To reach the on-line copy of article:

http://www.isguc.org/?p=article\&id=462\&vol=13\&num=2\&year=2011

Makale İçin İletişim/Correspondence to:

Ali FIKIRKOCA: afikir@politics.ankara.edu.tr, arzukalemci@cankaya.edu.tr 
(C) 2000- 2011

"İşGüç" Endüstri İlişkileri ve İnsan Kaynakları Dergisi

"İşGüç" Industrial Relations and Human Resources Journal

Nisan/April 2011, Cilt/Vol: 13, Say1/Num: 2

ISSN: 1303-2860, DOI: 10.4026/1303-2860.2010.179.x

Editör/Editor-in-Chief

Aşkın Keser (Kocaeli University)

Editör Yardımcıları/Co-Editors

K.Ahmet Sevimli (Uludağ University)

Gözde Yılmaz (Kocaeli University)

Uygulama/Design

Yusuf Budak (Kocaeli Universtiy)

\author{
Yayin Kurulu / Publishing Committee \\ Dr.Zerrin Firat (Uludă̆ University) \\ Doç.Dr.Așkm Keser (Kocaeli University) \\ Prof.Dr.Ahmet Selamoğlu (Kocaeli University) \\ Yrd.Doç.Dr.Ahmet Sevimli (Uludağ University) \\ Yrd.Doç.Dr.Abdulkadir Şenkal (Kocaeli University) \\ Yrd.Doç.Dr.Gözde Yilmaz (Kocaeli University) \\ Dr.Memet Zencirkıran (Uludă̆ University)
}

Uluslararası Danışma Kurulu / International Advisory Board

Prof.Dr.Ronald Burke (York University-Kanada)

Assoc.Prof.Dr.Glenn Dawes (James Cook University-Avustralya)

Prof.Dr.Jan Dul (Erasmus University-Hollanda)

Prof.Dr.Alev Efendioğlu (University of San Francisco-ABD)

Prof.Dr.Adrian Furnham (University College London-İngiltere)

Prof.Dr.Alan Geare (University of Otago- Yeni Zellanda)

Prof.Dr. Ricky Griffin (TAMU-Texas AEM University-ABD)

Assoc. Prof. Dr. Diana Lipinskiene (Kaunos University-Litvanya)

Prof.Dr.George Manning (Northern Kentucky University-ABD)

Prof. Dr. William (L.) Murray (University of San Francisco-ABD)

Prof.Dr.Mustafa Özbilgin (University of East Anglia-UK)

Assoc. Prof. Owen Stanley (James Cook University-Avustralya)

Prof.Dr.Işık Urla Zeytinoğlu (McMaster University-Kanada)

Danışma Kurulu / National Advisory Board

Prof.Dr.Yusuf Alper (Uludağ University)

Prof.Dr.Veysel Bozkurt (Uludağ University)

Prof.Dr.Toker Dereli (Işık University)

Prof.Dr.Nihat Erdoğmuş (Kocaeli University)

Prof.Dr.Ahmet Makal (Ankara University)

Prof.Dr.Ahmet Selamoğlu (Kocaeli University)

Prof.Dr.Nadir Suğur (Anadolu University)

Prof.Dr.Nursel Telman (Maltepe University)

Prof.Dr.Cavide Uyargil (İstanbul University)

Prof.Dr.Engin Yildirum (Sakarya University)

Doç.Dr.Arzu Wasti (Sabancı University)

Dergide yayınlanan yazılardaki görüşler ve bu konudaki sorumluluk yazarlarına aittir.

Yayınlanan eserlerde yer alan tüm içerik kaynak gösterilmeden kullanılamaz.

All the opinions written in articles are under responsibilities of the outhors.

None of the contents published can't be used without being cited. 


\title{
Küreselleşme ve Makro-Kurumsal Teori: Bir Literatür Taraması
}

\author{
Globalisation and Macro-Institutional Theory: \\ A Literature Survey
}

\author{
Ali FIKIRKOCA \\ Ankara Üniversitesi Sbf, İşletme Bölümü
}

\author{
R. Arzu KALEMCi \\ Çankaya Üniversitesi, İibf, İktisat Bölümü
}

\begin{abstract}
Özet:
Bu çalışmada örgüt kuramı içindeki makro-kurumsal yaklaşımın küreselleşme tartışmalarına getirdiŏi önemli açılımlar değerlendirilmektedir. Çalışmada makro-kurumsal bakış açısıyla geliştirilen bu açılımların gelişimi, bunların küreselleşme tartışmaları içinde nereye tekabül ettiğg ve ne gibi yeni bakış açıları ortaya koyduğu incelenmektedir. Çalışmada makro-kurumsal yaklaşımların getirdiği sonuçlardan yola çıkarak, genel nitelikli küreselleşme tartışmalarında ele alınan üçlü tasnife ek olarak 'aşırı küreselleşmeci makro kurumsalcı yaklaşımlar', 'şüpheci makro kurumsal değerlendirmeler' ve 'dönüşümselci makro kurumsal perspektifler' başlıkları altında yeni bir sinıflama önerilmektedir.
\end{abstract}

Anahtar Kelimeler: küreselleşme, aşırı küreselleşmeciler, kuşkucular, dönüşümselciler, yakınsama, ıraksama, melezleşme, makro kurumsal yaklaşım.

\begin{abstract}
:
The diversity of differing point of views on the "Globalisation" debate can be classified under three main headings. These are the hyperglobalisers, the sceptics and the transformationalists. In this study we argued that this classification can be enriched with the help of macro institutional approaches. Although there are many empirical and literature survey studies related to macro institutional theories, none of them evaluate this literature by specifically analysing what these aproaches have to offer on the analysis of the effects of globalization. In this study we interpreted the findings of macro institutional approaches through the lens of the three main perspectives of globalization. In the study, we proposed a new classification with the help of findings of the macro institutional studies. This classification is based on the three title that is; hyperglobaliser macro institutional approaches, sceptic macro institutional approaches and transformationalists macro institutional approaches. We believe that this classification contributes to the globalization literature by integrating macro institutional insights into the globalisation debate.
\end{abstract}

Keywords: globalization, hyperglobalisers, sceptics and transformationalists, macro institutional approaches, convergence, divergence, hybridisation. 


\section{GiRiş}

Son y1llarda belki de sosyal bilimlerde üzerinde en fazla tartışılan konulardan biri 'küreselleşme' olmuştur. Küreselleşme kavramı ile ilgili genel sav, ulusal kültürlerin, ulusal ekonomilerin ve ulusal sinırların çözüldüğü, sosyal hayatın büyük bölümünün küresel süreçler tarafından belirlendiği bir çağ olmasıdır (Hirst ve Thompson, 1996: 26). Dolayısıyla küreselleşmenin işletmecilik yazını açısından önemini vurgulamadan önce bu olgunun üzerindeki tartışmaları anlamamiz ve bir tanım geliștirmemiz gereklidir. Burada Held et al. (1999) sağladığı, küreselleşme tartışmalarının üçlü şekilde tasnif edilmesi faydalı bir yaklaşım olarak kabul edilebilir. Bu yazarlar, küreselleşme tartışmacılarını üç kategoride analiz etmişlerdir. Bunlar; aşırı küreselleşmeciler (hyperglobalisers), kuşkucular (sceptics) ve dönüşümselciler (transformationalists).

Aşırı küreselleşmecilerin pozisyonu en iyi şekilde yazar Kenichi Ohmae'nin (1995) düşüncelerine bakılarak anlaşılabilir. Bu yazara göre küresel bir ekonominin ortaya çıkmış olması, küresel yönetişimi amaçlayan kurumların vücut bulması ve kültürlerin küresel yayılımı ve melezleşmesi süreçleri ulus devletin ortadan kalktığ 1 yepyeni bir dünya düzenine işaret etmektedir. Finans piyasalarında dünya ölçeğinde yaşanan bütünleşme eğilimleri ve ulaşım/iletişim teknolojilerinde yaşanan köklü yenileşimler özellikle zamanın sıkıştırılması yoluyla mekânı anlamsız kılmaktadır (Harvey, 1994).

Buna karşılık kuşkucular ise ulussuzlaşma veya piyasaların küreselleşmesi gibi kavramların dünyadaki mevcut iktisadi durumun aşırı abartılı bir yorumu olarak değerlendirmektedirler ${ }^{1}$. Kuşkucular küreselleşmenin dünya iktisadi ilişkilerinde ciddi bir yeniden yapılandırmaya yol açtığı görüşüne karşı çıkarak ulus-devletlerin dünya iktisadi faaliyetleri üzerindeki egemenliğinin sürdügüüe vurgu yapmaktadirlar.

Dönüşümselciler ise, kuşkucular ve aşırı küreselleşmecilerin tersine, mevcut durumu küresel bir dünyanın var olup olmadığı sorusuna kesin bir yanit vererek değerlendirmeyi yanlış bulmaktadırlar. Dönüşümselciler, kuşkucuların küresel bir piyasanın ortaya çıkmadığına dair görüşlerine katılmakta ama bunun küreselleşme gerçeğini tamamıla dışlayan bir sonuca götürmemesi gerektiğini iddia etmektedirler. Bu yaklaşıma göre küreselleşme devletleri, toplumları, ekonomileri, yönetişim kurumlarını ve dünya düzenini dönüştüren bir güç olarak kabul edilmelidir². İsletme yazının son otuz yılında filizlenmeye başlayan makro-kurumsal yaklaşımların da küreselleşme tartışmalarına getirdiği önemli açılımlar ve katkılar söz konusudur. Ülkemizde de makro kurumsal çalışmalara yönelik ampirik araştırmalar (örn; Özen ve Berkman, 2007; Üsdiken, 2009) ve genel yazın taramaları mevcut olmakla beraber bu yazinın küreselleşme hakkındaki tespitlerini sistematik bir değerlendirmesi yapılmamıştır. Biz bu nedenle bu çalışmada, yukarıda değinilen genel nitelikli küreselleşme tartışmalarında ele alınan üçlü tasnif yöntemini makro kurumsal yaklaşıma uyarlayarak söz konusu yazının elde ettiği bulguları küreselleşmeci,

1 Kuşkucuların küreselleşme tartışmalarındaki konumunu Hirst and Thompson'ın (1996) çalışmalarına bakarak anlayabilmek mümkündür. . Bu yazarlar küreselleşmeyle ilgili olarak beş önemli değerlendirmede bulunmaktadırlar. Birinci olarak, günümüz iktisadi entegrasyon seviyesinin Klasik Altın Standardı dönemine göre (1870-1914) göreceli olarak çok ciddi bir farklılık göstermediği tespit edilmiştir. Uluslararası ticaretin ve sermaye hareketlerinin dünya ekonomisi içindeki payı hemen hemen aynı kalmıştır. İkinci olarak, ÇUŞ'ların (Çok Uluslu Sirketler) toplam satış, üretim ve varlıklarının büyük çoğunluğunun ülkelerinde bulunduğu tespit edilmiştir. Üçüncü olarak, yabancı sermayenin büyük çoğunluğunun gelişmiş ülkelerde olduğu bilinmektedir. Dördüncü olarak, uluslararası iktisadi hareketliliğinin Triad (Asya, Kuzey Amerika ve AB) bölgeleri içinde yoğunlaştığı ve son olarak, gelişmiş ülkelerin uluslararası piyasaları düzenleyebilme kabiliyetinin devam ettiği gözlenmektedir.

2 Dönüşümselciler küreselleşmeyi 'toplumsal ilişkilerin ve işlemlerin coğrafi örgütlenmesindeki dönüşümlerin ortaya çıkardığı ve - genişleme, kuvvetlenme, hız ve etki açısından tayin edilen - kıtalar aşırı veya bölgelerarası akımlar, eylem şebekeleri, etkileşimler ve iktidar ilişkilerinde vücut bulan süreçler bütünü' olarak tanımlayarak, bizim de bu çalışmada benimsediğimiz, kapsamlı bir kavramsal çerçeve sunmaktadırlar (Held et al., 1999). 
şüpheci ve dönüşümselci başlıkları altında değerlendirmekteyiz. Çalışmanın yöntemini literatür taraması oluşturmaktadır. Çalışmada küreselleşme kavramını makro kurumsal yaklaşım ile ele alan çalışmalar incelenmiş ve bu çalışmalar küreselleşmeye ilişkin yapılan temel üç tartışma- aşırı küreselleşmeciler (hyperglobalisers), kuşkucular (sceptics) ve dönüşümselcilerdir (transformationalists) - çerçevesinde değerlendirilmiştir. Bu değerlendirme 1şığında aşağıda da göreceğimiz üzere makro kurumsal bakış açısının getirdiği sonuçlardan yola çıkarak kabaca yeni bir üç tip-'aşırı küreselleşmeci makro kurumsalcı yaklaşımlar', 'şüpheci makro kurumsal değerlendirmeler' ve 'dönüşümselci makro kurumsal perspektifler- siniflandirmayı önermekteyiz. Biz böyle bir değerlendirmenin, makro-kurumsal çalışmaların küreselleşme yazınına yaptıkları katkıların temel koordinatlarının belirlenmesine rehberlik edeceğini düşünmekteyiz. Buna ek olarak, biz bu çalışma ile akademik dünyada dolaşıma girdiği andan itibaren inter-disipliner bir niteliğe bürünen küreselleşme kavramina kurumsal bakış açısı ile yaklaşmak üzere bu kavramin içeriğinin daha da zenginleşeceğini ve bu anlamda sosyal bilimciler için önemli imkânlar sunacağına inanmaktayız. Çalışma şu şekilde örgütlenmiştir: birinci bölümde küreselleşmenin yakınsamacı sonuçlarını vurgulayan aşırı küreselleşmeci yaklaşım olarak tasnif ettiğimiz kurumsal yaklaşımlar ortaya konmaktadır. İkinci bölümde küreselleşme kuşkucularıyla paralel görüşler sunan rraksamacı kurumsal görüşler ele alınmaktadır. Çalışmanın üçüncü bölümünde iş uygulamalarında ülkeler arası etkileşimleri ve melezleşme süreçlerini öne çıkaran dönüşümselci kurumsal çalışmalar değerlendirilmektedir. Sonuç bölümünde ise makro-kurumsal bakış açısının küreselleşme tartışmaları için getirdiği katkılar vurgulanmaktadir.

\section{AŞIRI KÜRESELLEŞMECI MAKRO- KURUMSAL YAKLAŞIMLAR}

Aşırı küreselleşmeci olarak nitelediğimiz makro-kurumsal çalışmalar çoğunlukla kü- reselleşmeyi işletme fikirleri ve uygulamalarının "ev sahibi" ülkeden yurtdışına aktarılması sürecinde ortaya çıan yakınsama/benzeşme (convergence) eğilimlerinin kökenini ve başarısını sağlayan unsurlara odaklanmaktadır. Makro-kurumsal bakış açısının küreselleşmenin yarattığ 1 yakınsama etkilerine/taklitçiliği özendiren baskılara dikkat çeken tarihsel çözümlemelerinde, aşağıda da göreceğimiz üzere, farklı değerlendirmeler söz konusudur. Bu çalışmalar dünyadaki kapitalist iş bölümünün getirdiği rekabetin sonucunda oluşabilen eşitsizlik ve hiyerarşiye dayalı güç ilişkileri içinde ortaya çıktığ1 vurgulanan Amerikanlaşma veya Japonlaşma etkileri (is modellerinin taklit edilmesi) ile uluslararası işletmecilik faaliyetlerinin değişen yapısına odaklanmıştır.

\subsection{Yakınsamacı Hâkimiyet Etkileri}

Makro-kurumsal yaklaşımların genelde, farklı coğrafyalarda ortaya çıkan kültürel ve toplumsal dinamiklerin örgüt yapıları üzerindeki farklılaşan etkilerini öne çıkardıkları bilinmektedir. Ancak bu alanda çalışan bazı yazarların küreselleşme bağlamında yaptıkları tespitlerde zaman zaman "en iyi işletmecilik" uygulamalarının yayılmasının yarattığ yakınsama dinamiklerine dikkat çektiğini de gözlemlemekteyiz. Küreselleşmeci görüşleri destekleyen bu savlar, genelde iş modellerinin yayılmasına yönelik ampirik kanıtları öne sürmüşlerdir. Bu bağlamda ortaya çıkan yazın, ilginç bir şekilde, küreselleşmeyi batıya öykünme girişimleriyle bir tutan (örneğin bkz. George Ritzer'in MacDonaldlaşma tezi) tartışmalardan farklı olarak hem batı (Amerikanlaşma) hem de doğu (Japonlaşma) kaynaklı yakınsama dinamiklerine dikkat çekmiştir.

Makro-kurumsal çalışmaların örgütlenme modellerinde ülkeler arası yakınsamayı/benzeşmeyi ele alan yaklaşımlarına ilişkin ilk örneği 'Fordist' üretim paradigmasına ilişkin tartışmalarda görebiliriz. Yirminci yüzyılın ortalarından itibaren ağırlıklı olarak sanayileşmiş ülkelerde filizlenen ölçek ekonomisine ve uzmanlaşmaya dayalı büyük firma yapılanmalarının yaygınlaşması burada ele alınan 
temel meseledir. "Amerikanlaşma" meselesini makro-kurumsal çerçevede ele alan yaklaşımların temel iddiası, verimliliği arttırmak amacıyla İkinci Dünya Savaşı sonrasında Amerikan sanayi sisteminin yükselen başarısının, özellikle Avrupa ve Japon firmalarının Amerikan idari uygulamaların benimsemesinde etkili olduğu yönündedir (Frenkel ve Shenhav, 2003). Amerikanlaşma olarak anılan bu süreç sonucunda ise uluslararası üretim ve örgütsel yöntemler arasındaki yakınsama gittikçe artmıştır (Westney, 1987; Strang ve Meyer, 1993; Chandler, 1990; Djelic, 1998, Kipping ve Bjaenar, 1998, Guillen 1994). Djelic (1998) bu yakınsamanın bizatihi kendisinin Avrupa'da Marshall yardımları s1rasında oluşturulan Amerikan menşeli kurumsal mekanizmalarin zorlamasiyla oluştuğunu vurgulayarak örgütsel eşbiçimliliğin kurumsal temellerine dikkat çekmiştir.

Makro-kurumsal yazının bu konuda yaptı̆̆1 en önemli katkılardan biri 'Fordist' işletmeyi basit bir teknik model olmanin ötesinde toplumsal ve siyasi faktörler tarafından şekillenmiş bir yapılanma olduğu vurgusudur. $\mathrm{Bu}$ noktada, örneğin Fransız düzenleme okulu yazarlarının, 'Fordizmin' dayandığı kitle üretimini ulusal ekonomilerin denetlediği kredi mekanizmaları yoluyla desteklediği tüketim artışları ile özendiren ve böylelikle ulusal seviyede arz ile talebi senkronize eden kurumsal düzenlemelere referansla açıkladığını görmekteyiz. Aynı şekilde Sabel ve Zeitlin'in (1984) geliştirdiği “üretim alternatifleri" paradigmasinin da 'Fordist' firmaların sahip olduğu büyük ölçeklerin sınai yoğunlaşmayı özendiren "ulusal şampiyonlar" yaratma yönündeki yoğun politika müdahaleleri sonucu ortaya çıktığını gösteren analizleri mevcuttur. Bu noktada Amerikan modelinin, küresel kapitalist birikim sürecinin tarihsel bir aşaması olarak, belli iktisadi zorunluluklar açısından ele alan düzenleme okuluyla "üretim alternatifleri" yaklaşımı arasındaki farklılık da belirginleşmektedir. Yakınsamayı kabul etmekle beraber bu ikinci yaklaşım 'Fordizmi' -ölçek ekonomisinin zanaatkârlığa dayalı esnek üretim biçimlerine karşı mutlak teknolojik üstünlüklere referans veren düzenleme ekolünün tersine- bir tekno-iktisadi zorunluluk olmaktan ziyade tarihsel süreçteki farklı aktör gruplarının arasındaki siyasi mücadele ve tesadüfler sonucu ortaya çıktığını savunmaktadır. Buna karşın düzenleme okulu 'Fordist' sistemin getirdiği verimlilik artışlarının düşük uluslararasılaşma seviyelerine dayalı savaş sonrası iktisadi ortamında, bir diğer deyişle ulusal ekonomik yönetimin hâkim olduğu bir dönemde mümkün olabileceğini vurgulamaktadir.

Bu açıdan bakıldığında, düzenleme okulunun seksenli yıllardan sonra artan uluslararasılaşma eğilimlerinin ${ }^{3}$ 'Fordizmin' sonunu hazırlaması yönündeki açılamaları kuramsal manada ciddi bir içsel tutarlılık barındırmaktadır.

Yakınsamayı savunan farklı bir kurumsalcı görüş ise teknolojiler ve işletmecilik uygulamalarının ülkeler arası aktarılması sürecinin kurumsal farklılıklar tarafından engellenmeden de gerçekleşebileceğini, yani bazı değişikliklerin kurumsal olarak nötr olduğunu vurgulamaktadır. Gerçekten de yurtdişından ithal edilen bir takım yeni ürün teknolojileri ve örgütsel uygulamaların alıcı ülkede geniş kapsamlı uyum çabaları gerektirmeden gerçekleştirebildiğini görmekteyiz.

Kogut (2000) buna örnek olarak yarattığ1 sonuçlar itibariyle ciddi farklılaşmalara yol açmakla birlikte, Doğu Avrupa'da sosyalizm sonrası dönemde görece pürüzsüz bir şekilde yayılan -ABD'nin savunduğu liberal fikirlerden esinlenen- özelleştirme uygulamalarına değinmektedir. Aynı şekilde Witthington v.d.., (2000) büyük Amerikan şirketlerinin 20. yüzyılın başında benimsediği ve Chandler'in (1990)M-formu ismini verdiği çeşitlenmeye dayalı holding tipi örgüt yapılarının Avrupa'nın pek çok başat ülkesinde varlığını sür-

3 Burada söz konusu olan uluslararasılaşan bir ekonomide hem ücretlerin küresel rekabet sonucunda ulusal seviyede belirlenememesi, hem de küreselleşen finansal mimarinin sonucu olarak iç tüketimi canlandıran kredi mekanizmaları üzerindeki hükümet denetiminin azalması yönündeki eğilimlerdir. 
dürdüğünü gözlemlemektedir.

Kurumsal kuramın yakınsama tartışmalarına yaptıkları en önemli katkılardan biri de Smith ve Meiskins'in (1995) çalışmasında vücut bulmuştur. Yazarlar küreselleşmenin getirdiği benzeşme dinamiklerini tarihsel bir perspektifle -özellikle de kapitalizmin evrimine referansla- ele almaktadır. Uluslararası kapitalist rekabetin tarihine baktığımızda her teknolojik devrim, çoğunlukla ulus-devletin sınırları içinde olmak üzere, belli bir coğrafyada ortaya çıkmaktadır. .Bu nedenle de "hâkimiyet etkilerinden" bahsedilmektedir. İlk olarak Smith ve Meiskins' in (1995) ortaya attığı bu terim 1990'lı yıllarda toplam kalite uygulamalarının (TKY) yaygınlaşmasıyla başlayan "Japonlaşma" ile baş etmeye çalışan firmaların uluslararası örgütsel incelemelerinin daha iyi anlaşılması için geliştirilmiştir. Smith ve Meiskins'in (1995) de savladığ gibi kapitalizmin tarihine bakıldığında ülke ekonomileri arasında her zaman bir hiyerarşi olduğu kesindir, ve genellikle hâkim konumda olanlar, üretimin örgütlenmesi veya işbölümüne ilişkin yeni yöntemleri geliştiren kesim olarak bilinmektedir Hâkim ülkenin sınai üstünlüğünü temin eden unsurlar genel olarak geriden gelen ülkeler tarafından taklit edilmesi gereken bir "başarı öyküsü" olarak kabul görür (Smith and Meiskins, 1995). Burada hâkim konumdaki ülke firmalarının ve sanayilerinin yenilikçi performansının meydan okumasıyla karşı karşıya olan taklitçi ülke firmalarının esas amacı rekabetçi üstünlüğü elde etmektir. Bu durum taklit eden ülke için teknolojinin ve/veya en iyi işletmecilik modellerinin transferini gerektirebilir. Yazarların hâkimiyet etkileri çerçevesinde ele aldığı Japonlaşmanın, işlevsel bölümlenmeye dayalı 'Fordist'örgütlenmedeki parçalı yapıyı, iş süreçlerini bölümler ve takımlar arası çalışmaları teşvik ederek aşmaya dayanan bir model olduğu vurgulanmaktadır.

Zaman zaman 'Toyotizm' olarak da nitelendirilen bu üretim tarzının yaygınlaşmasını ele alan Abo'nun (2006) çalışması Japon ÇUŞ’larının bu alandaki rolünü kapsamlı bir şekilde ele almıştır ${ }^{4}$. Ele edilen bulgular bu ÇUŞ'ların faaliyetleri sonucunda Japon kaynaklı hâkimiyet etkilerinin üç kıtada yakınsama etkileri yarattığını vurgulamaktadır. Kita Avrupa'sının çeşitli ülkelerinde iş güvencesine ve çalışanların yönetimde temsiline dayanan mevcut yasal düzenlemelerin -çalışanların şirketine yüksek seviyeli sadakat göstermesi ve hayat boyu istihdam imkânı sağlaması- Japon işletmecilik ortamına gösterdiği benzerlik sebebiyle TKY uygulamalarının yayılımını kolaylaştırmıştır. Japon çok ulusluları küçük uyarlamalarla hafif melezleşen bir örgüt yapısını Japon iş sistemin temel niteliklerini yansıtacak biçimde Asya, Avrupa ve $A B D^{\prime}$ de - ortaya çıkan farklı benimseme hızlarına rağmen- yaygınlaştırmayı başarmışlardır.

Benzer olarak Avrupa'da, İngiltere'ye yönelik yapılan çalışmalarda, buradaki özellikle alt ve orta kademe çalışanların işi sahiplenmelerini özendiren İnsan Kaynakları uygulamalarının, Japon sisteminin katılımcılığ1 özendiren yönetim anlayışıyla benzerlik arz ettiği ileri sürülmektedir. Araştırmacılar İngiltere'deki yerel aktörlerin, toplam kalite benzeri bu tarz uygulamaları yaygınlaştırarak, ülkenin sanayi ilişkilerini Japon sistemine yaklaştıran bir dönüşüm sürecine soktuklarını vurgulamaktadırlar (Oliver ve Wilkinson, 1992).

Aglietta ve Bretton (2001) ise 20. yy. sonunda Japonya/Almanya eksenli 'Post-Fordist' meydan okumalar karşısında tekrardan yenilenen ve güçlenen Amerikan ekonomisinin arkasındaki itici güç olarak görülen "yeni ekonomi" paradigmasının kurumsal altyapısını inceleyerek yakınsama tartışmalarına önemli katkılarda bulunmuşlardır. Araştırmacılar, ABD'nin bilişim teknolojilerine dayalı sektörlerde yaptı̆̆ 1 atılımı tetiklediği ileri sürülen bu yeni Amerikan menşeli iş modeline yönelik kurumsal temelli eleştiriler sun-

4 Araştırma Japon ÇUŞ’larının kendi ülkelerindeki iş uygulamalarını yurtdışına ihraç etme çabalarını, faaliyet gösterilen ABD, Avrupa ve Asya'daki yurtdışı şubelerinde 10 yıllık bir süreçte yönetici ve çalışanlarla yapılan anketler yoluyla ele almıştır. 
muşlardır. Yazarlar, söz konusu modelin sağladığ1 rekabetçi üstünlügü açıklamada girişim sermayesi ve çalışanların hisse senedi sahipliği gibi uygulamaların rolüne yapılan vurguyu eleştirmektedirler. Çünkü bu araştırmacılara göre, başarılı olduğu savunulan bu yeni modelin arkasında yatan asıl itici güç, 80'li y1llardan beri süregiden, mali sistemdeki deregülasyona yönelik kurumsal düzenlemelerdir. Söz konusu düzenleme çabalarının Amerikan varlık fiyatlarında yarattığı spekülatif balonların internet teknolojileri etrafında yoğunlaştığı vurgulanmaktadır. Bu çözümlemeye göre, yeni kurulan internet şirketleri sahip oldukları teknolojik potansiyel etrafında oluşan aşırı yüksek finansal beklentileri manipüle etmişlerdir. Bu ileri teknoloji şirketleri girişim sermayesi firmaları aracılığıyla borsadaki yatırımcılardan yüksek miktarlarda fon toplama kabiliyetine erişmişlerdir. Aynı şekilde bilişim sektöründe faaliyet gösteren daha eski şirketler de bu süreçte değerlenen hisse senetlerinin bir kısmın satın alma ve birleşmelerde nakit yerine kullanarak 1990'ların sonundaki iyimser mali ortamdan nemalanmışlardır. Borsaya dayalı bu sanal modelin, internet şirketlerinin şişkin hisse fiyatlarından ötürü başarılı addedildiğini, diğer bir deyişle finansal dalgalanmalara dayalı eski kapitalist ekonominin dinamiklerinin devam ettiği vurgulanmaktadır. Bu tarz bir modelin başka ülkelerde de taklit edilmesi dünya ekonomisini finansal olarak istikrarsızlaştıran küresel çaplı olumsuz bir iktisadi yakınsama yaratmıştır.

Sonuç olarak küreselleşmenin etkilerini yakınsama dinamikleri açısından ele alan makro-kurumsal çalışmalar, "en iyi işletmecilik" uygulamalarının yaygınlaşmasını sonuçlarıyla beraber ele almaktadırlar. Taklit edilen iş modellerinin ortaya çıktıkları kurumsal çerçevenin getirdiği içsel çelişkilere, sınırlılıklara dolayısıyla da varoluş koşullarına dikkat çekerek yazına anlamlı içgörüler sağlamaktadırlar. Yakınsamacı görüşler tespitlerini güçlendirmek için uluslararası işletmecilik faaliyetlerindeki gelişmeleri de ele almaktadırlar.

\subsection{Ulus Ötesi Şirketler ve Uluslar arası Standartlar}

Morgan (2001) 1980'lerden itibaren ortaya çıkan küresel işletmelerin farklı üretim coğrafyaları arasında bağlantılar kurarak ulus ötesi niteliğe bürünen bir iktisadi uzamı kurgulamasına dikkat çekmektedir. Küresel şirketler, çok uluslu şirketlerden farklı olarak hem yatay hem de dikey iletişime olanak tanımakta, yöneticilerin çeşitli şubeler arasında dolaşımı söz konusu olmaktadır. Çalışanlara resmi ve gayri resmi mekanizmalar aracil1ğıyla ulus ötesi öğrenme ve işbirliği olanakları tanınmaktadır. Üst düzey yöneticiler ise farklı ulusal köken ve deneyimlerden gelmektedir. Morgan'a göre bu tür bir küresel şirket modeline, görgül bulgulara dayanarak, daha karmaşık ve çeşitlilik gösteren bir yapıya sahip olan İngiliz ve ABD firmaları arasinda rastlanmaktadır. Buna ek olarak Alman firmalarının da bu yönde gelişme gösterdiği belirtilmektedir.

Geppert v.d. (2010) ÇUŞ’ların bu yeni uzamsal mekanı kendi örgütleri içinde geliştirdikleri yönetimsel yap1 ve uygulamaları küresel çapta yaygınlaştırarak kurguladığını öne sürmektedirler. Özellikle üretim ve finans alanında ISO veya BIS gibi uluslararası örgütlerin getirdiği ürün (ISO-9000) ve muhasebe standartlarının (Basel) önemli öykünmeci ve normatif türdeşleşme eğilimleri getirdiği vurgulanmaktadir. Bu tarz standartlaştırma girişimleri, hukuki yaptırımlara dayanmamakla beraber, uluslararası piyasalara ürettiği malları satmak isteyen ya da küresel finans piyasalarından fon temin etmek isteyen ve yeterli marka bilinirliğine sahip olmayan firmalar üzerinde, ciddi bir küresel piyasa disiplini getirerek, etkili olduğu saptanmıștır (Hancke ve Casper, 2000). Buna ek olarak Morgan (2001) işletmecilik odaklı medya, eğitim ve danışmanlık firmalarının özellikle şirket yönetişiminde hissedarların ç1karlarını öne çıkaran "Anglo-Sakson" tipi kapitalist iş uygulamalarının yaygınlaştırılmasında türdeşleştirici etkisine vurgu yapmaktadır.

Özellikle 1980'li yıllarda yaygın olarak ge- 
liştirilen yakınsamacı makro-kurumsal açıklamalar özellikle kapitalizmin tarihsel evrimine odaklanan yaklaşımlardan oluşmaktadır. Diğer taraftan, bir sonraki bölümde de ele alacağımız üzere, kapitalist dönüşümlerin ve çeşitliliğin aynı zamanda coğrafi temelleri olduğunu iddia eden şüpheci makro-kurumsal görüşler, işletmecilik modellerinin yaygınlaşmasının alıcı ülkelerdeki kurumsal farklıklardan dolayı mümkün olmayabileceği durumları ele almaktadır.

\section{3.ŞÜPHECI MAKRO-KURUMSAL DEĞER- LENDIRMELER}

Küreselleşme kavramını sorgulayan birçok makro-kurumsal araştırmacı, ulus devletlerin küreselleşme ile beraber önem ve ağırlıklarını kaybedip kaybetmediği noktası üzerinde yoğunlaşmaktadır. Bu görüşe göre ekonomik faaliyetlerin ve örgütlerin tasar1mında, ulus devletin/iş sistemlerinin ağırlığı, küreselleşmenin sınırlı boyutu hakkında fikir vermektedir. Bu noktada şüpheciler ulusal iş sistemlerinin, bunları oluşturan kurumların çeşitliliği ve tamamlayıcılığı ile bunların ÇUŞ’ların örgütsel yapıları ve uluslararasılaşması üzerindeki etkilerini göstererek dünya ekonomisindeki ulus devletlerin başat konumuna gönderme yapmaktadır.

\subsection{Ulusal farklılıkların direnişi? Kurumsal Tamamlayıcılıklar}

Küreselleşme taraftarlarının liberal piyasa ekonomi modelini tüm dünya için nihai bir hedef ve tarihin sonu olarak sunmaya çalıştığ 1 bir dönemde, kurumsal çalışmaların ulus devletlerin çeşitliliğine vurgu yapan çalışmaları önemli bir tezat oluşturmuştur. Avrupa'da, ülkeler arası karşılaştırmalı araştırmalar yapan Aix-Grubu (Maurice et. al., 1982), farklı ülkelerdeki iş ortamı örgütlenmesindeki çeşitliliği sürdüren 'topluma özgül etkileri' - yani her ülkenin politik-ekonomi sistemi, tarihi, gelenekleri ve kültürü açısından özgüllüğünü - ortaya koymuşlardır. Richard Whitley (1999) tarafından ortaya konan ve 'Ulusal İş Dizgeleri' ismiyle anılan kuramsal yaklaşım, topluma özgül etkiler okulunun görüşlerini çok sayıda ülkedeki iş dizgelerinin örgütlenmesine etki eden ulusal faktörlerin etkilerini analiz ederek genişletmiştir. Amable (2000) bu etkileşimin daha iyi incelenebilmesi için kurumsal tamamlayıcılık kavramından faydalanılması gerektiğini ileri sürmektedir. Bu kavram, aşağıdaki örnekte ayrıntılı bir şekilde gösterileceği gibi, farklı alanlardaki kurumsal düzenlemelerin bir araya gelip kenetlenerek -belirli bir zaman dilimi süresince- görece tutarlı ve istikrarlı bir yap1 oluşturması olarak tanımlanmaktadır. Diğer bir deyişle bir kurumsal düzenlemenin etkinliği ancak onu destekleyen başka bir kurumsal düzenlemenin mevcudiyetiyle mümkündür. Böylece sadece bir alandaki kurumsal düzenlemeleri değiştirerek, yani sistemin genel tutarlılığını göz önünde bulundurmadan yapilacak kurumsal düzenlemeler başarısız olma riski taşımaktadır.

Bu konuya somut bir örnek vermek amacıyla Whitley'in (2000) çok daha detaylı olarak ortaya koyduğu kapitalizmin coğrafi çeşitliliğini (kuramsal açıklık ve basitlik adına) ikili bir sınıflandırmaya indirgeyerek iki tür ulusal iş dizgesine odaklanmak konunun daha iyi kavranması açısından faydalı olacaktır (bkz. Casper ve Whitley, 2002; Hall ve Soskice, 2001). Bunlardan ilki, kökten yenilik stratejilerini destekleyen Serbest Piyasa Ekonomileri (SPE) ve bir diğeri aşamalı yenilik stratejilerini destekleyen Eşgüdümlü Piyasa Ekonomileridir (EPE).

Serbest Piyasa Ekonomileri işletme dizgelerinin kurumsal tamamlayıcılıkları şu unsurlardan oluşmaktadır: (a) işe alma ve işten çıkarmayı kolaylaştıran esnek çalışma uygulamaları, (b)akademik topluluğun risk alma ve girişimciliğini destekleyen ve patent sahiplerine getirdikleri yeniliklerin ticari faydalarını güvence altına alarak sıkı fikri mülkiyet hakları koruması sağlayan bir bilim ve teknoloji politikası, (c)yüksek karlılık oranlarının sağlanması amacıyla firmalar üzerinde kısa vadeli baskılar oluşturan finans sermayesinin (borsanın) rolünü ön plana çıkaran bir mali sistem ve (d)ürün rekabet piyasasını anti-tröst yasalarıyla destekleyen bir "düzenleyici devlet" tarafından belirlenen kamu-özel sektör ilişkileri. 
Serbest Piyasa Ekonomilerinin sunduğu bu çerçeve, kökten (radikal) yenilikleri (inovasyon) ön plana çıkarmaktadır. Bu tür yeniliklerle uğraşan firmalar yüksek nitelikli personeli elde etmek ve güdülemek zorundadır. Nitekim bu tip firmalar belirsiz bir teknolojik çevrede faaliyet göstermekte ve buna bağlı olarak da şirketlerini ürün piyasasında rekabetin yoğun olduğu alanlardan çekerek yeni teknolojik alanlara yönlendirmek için hizlı bir yeniden yapılanmaya gitmek zorunda kalmaktadırlar. Esnek istihdam piyasaları bahsedilen SPE'lerdeki şirketlerin eski iş kollarındaki personelini azaltarak yeni iş kollarında ihtiyaç duydukları personeli istihdam etmelerine olanak sağlamaktadır. Bu çerçeve ileri teknoloji KOBI'leriin borsa yoluyla halka açılmasını teşvik ederek özellikle küçük girişimci şirketlerin ortaya çıkmasının desteklenmesinde (Silikon Vadisi örneğinde olduğu gibi) başarılıdır. Ayrıca bu tarz küçük yenilikçi firmaları kendi faaliyet alanlarına dahil eden büyük firmaların teknolojik olarak diri kalmaları da mümkün olabilmektedir (Amable and Petit, 2001 Burada sistemin sağladığı sıkı fikri mülkiyet hakları rejiminin getirdiği güvenceler sayesinde firmalar kökten yenilikçi buluşlarını,taklitçilere karşı koruyarak piyasada kendilerine yere açabilme imkanına kavuşmaktadırlar.Kökten yenilikçi firmalar çekirdek ürün ve teknolojilere odaklanarak karmaşık Ar-Ge çalışmalarına yoğunlaşmakta, örgütsel karmaşıklığ 1 ise minimize etmektedir. Burada çalışanların bireysel performansa dayalı teşvikler ve hisse senedi sahipliği yoluyla güdülendiği görülmektedir.

Diğer taraftan EPE'lerinin sunduğu çerçeve şu tamamlayıcılıklardan oluşmaktadır (a) uzun vadeli sanayi-bankacılık işbirliğini harekete geçirerek üretici sermayeyi ön plana çıkaran ve yapılan iş üzerindeki denetimi şirket çalışanlarıyla paylaşan (şirket yöneticilerine hissedarların kısa vadeli baskılarına dayanabilme imkanı tanıyan) bir mali sistem, (b)uzun vadeli işgücü güvencesi sağlayan kuvvetli sendikal yönelimler; geniş olarak tanımlanmış becerilere büyük yatırımlar yapan dayanışmacı kamu eğitim dizgesi, (c)patent- lerin sadece özel buluşlar için verildiği çok sıkı olmayan fikri haklar rejiminin eşlik ettiği devlet bilim ve teknoloji politikası ve (d) şirketler arası rekabet yerine dayanışmayı teşvik eden devlet-piyasa ilişkileri. EPE'lerinin temelini oluşturan kurumsal tamamlayıcılıklar aşamalı yenilikleri desteklemektedir. Bu tip bir sistem içinde yer alan şirketler, kamu politikalarıyla uyumlu olarak yeni ve riskli sektörlere girmekten kaçınırlar. Bu tarz firmalar birikimli olarak gelișen ve teknoloji yörüngesi tahmin edilebilir alanlara yatırım yapmaktadır. Aşamalı yenilikler geliştirmeye yönelen bu firmalar teknolojik altyapıları itibarıyla kolaylikla taklit edilebilme riskiyle karşı karşıya kalabilmektedir. Bu nedenle EPE şirketleri kendilerini rakiplerinden farklilaştırmada ileri teknolojiye yönelmekten ziyade mevcut teknolojileri destekleyecek tamamlayıcı örgütsel becerilere odaklanmaktadır. Burada, SPE şirketlerinden faklı olarak, teknolojik karmaşıklıktan ziyade örgütsel karmaşıklığın arttırılması yoluyla rekabet söz konusudur. 'Yenilikleri müşteriye özel hale getirip (sundukları ürünleri) ek hizmetlerle paketleyen bu tarz firmalar örgütsel özgüllüklerini arttırarak taklit edilebilme kolayl1ğını sınırlamaktadırlar' (Casper ve Whitley, 2002: 91). Böylece bahsedilen tipteki firmaların sahip olduğu eğitimli işgücü firmayı diğer firmalardan ayrıştırmasına yarayacaktır. Buna ek olarak bu tip şirketler örgütsel becerilere yatırım yapmak konusunda daha istekli olacaktır.

$\mathrm{Bu}$ firmalarda çalışanların sadece istihdam edildikleri şirkete özgü, dolayısıyla da başka bir kurumda kullanamayacakları, yetkinliklere yatırım yapmalarını teşvik eden unsur EPE'lerin sunduğu iş güvencesine yönelik garantilerdir.

Yukarıda değindiğimiz kurumsal tamamlayıcılıkların, küreselleşme taraftarlarının türdeşleşme iddialarının aksine, farklı ülkelerde farklı iş sistemleri ortaya çıkardığı, bunun da o ülkelerin hakim özel sektör aktörleri için farklı şirket yetkinliklerine tekabül ettiği öne sürülmektedir. Nihai olarak bu durumun, dünya ekonomisindeki iktisadi faaliyetlerin bütünleşme eğilimine paralel olarak, ülkele- 
rin farklı sektörlerde uzmanlaşmasına yol açtığı öne sürülmektedir. Kısacası kurumsal tamamlayıcılıkların tek tipleşme anlamında bir küreselleşmenin önünde engel teşkil ettiği ileri sürülmektedir (Hall ve Soskice, 2001). Ulus devletin iş sistemleri üzerindeki süregiden etkisini inceleyen bu tarz "kuşkucu" makro-kurumsal açıklamalar savlarını, ulus devletin iş dünyası üzerindeki geniş kapsamlı etki yaratabilme kapasitesini gündeme taş1yarak da perçinlemişlerdir.

Bu bağlamda devletler ve tamamlayıcı kurumların niteliğinin, ekonomik kontrol ve eşgüdüm bakımından homojen sistemlerin oluşumundaki etkisini inceleyen Whitley (2003), ulus devletlerin ekonomik alanda öneminin devam ediyor olmasın 6 önemli sebebe dayandırmaktadır. Öncelikle devletlerin politika yapıcı konumu, çıkar grupları ve benzer toplulukların ulusal düzeyde organize olarak devletin sağlayacağı kaynaklar ve meşruiyetten faydalanmaya çalışmalarına neden olmaktadır. Ulusal yasalar ve kurumlar özel sektördeki mülkiyet yapılarının başat belirleyicisidir. Üçüncü bir neden piyasaya giriş çıkış, anlaşmazlıklar ve rekabeti ilgilendiren düzenlemelerin ulusal kurumlar tarafından yapılmasıdır. Dördüncü neden, sermaye piyasalarına ilişkin düzenlemelerin genelde devletler tarafindan yapiliyor olmalarıdır. Beşinci neden işgücü piyasasının genellikle devlet tarafından yapilan düzenlemelere tabi olması, altıncı neden ise güven ve otorite ilişkilerinde yer alan aktörlerin ulusal politik ve yasal kurumların etkisinde hareket etmeleridir. Bu durumda, politik ve yasal kurumlar ulus devletlere göre ne kadar farklılık gösteriyorsa, firmaların yönetişim yapıları, stratejik öncelikleri ve örgütsel yetkinlikleri de o kadar farklılaşacaktır. Bu bağlamda Whitley (2003) uluslararası düzenleyici kurumların yetersizliğinin de ulus devletleri önemli kıldığını öne sürmektedir. Bunlar, teknolojik ve sektörel gelişimle ilgilenmek ya da piyasa firsatçılığına engel olmak gibi temel iktisadi faaliyetlerle ilgilenmek yerine, kaynak aktarımında şeffaflık ve güvenilirliği sağlamaya odaklanmakla yetinmektedir. Whitley (2003), tüm bu ulusal öl- çekli açıklamalarına ek olarak, uluslararası düzeydeki ekonomik faaliyetlerin düzenlenmesi ve eşgüdümleme çabalarının kırılgan yapılar aracılığıyla sürdürüldüğünü, bunların büyük şirketlerin veya büyük ulusal aktörlerin arasındaki geçici anlaşmalarla sınırlı kalıp yeterince merkezi/istikrarlı bir yapıya bürünemediğini ifade etmektedir

Bu yaklaşımın bir uzantısı olarak şüpheci makro kurumsal yaklaşımların yukarıda deginilen uluslararası ticari faaliyetlerin de aynı şekilde ulusal faklılıklardan etkilendiğini gösteren çalışmaları mevcuttur. Aşağıda göreceğimiz üzere, yakınsamac1 görüşün savunduğunun aksine, uluslararası işletmecilik üzerinde de rraksamacı etkiler tespit edilmektedir.

\subsection{Uluslararası işletmecilik ve traksama etkileri: Çok Uluslu Şirketler ve Ulusal Aidiyet}

Makro-kurumsal yazarların küreselleşmeye yönelik şüpheci tutumlarını destekleyen bir diğer bulgu da yapılan çalışmalarda ulusal aidiyetin ÇUŞ’ların örgütsel yapısı ve uluslararasılaşma stratejileri üzerindeki etkilerine ilişkin değerlendirmelerde ortaya çıkmiştır.

Lane'nin (1998) yaptığı çalışmada bir dizi örnek olay incelemesi sonucunda EPE kategorisindeki Alman ÇUŞ’ları ile SPE kategorisindeki İngiliz ÇUŞ’larının uluslararasılaşma desenleri karşılaştırılmıştır. Bu araştırmada Ulusal İşletmecilik Dizgelerinin ÇUŞ'ların yönetişimine de ciddi oranda etki ettiği gözlenmiştir.

EPE' lerinde ortaya çıkan firmaların ülkelerindeki mevcut kurumsal düzenlemeler sonucunda daha zor uluslararalılaştığ1 gözlemlenmiştir. Bu ülkelerdeki aktörlerin yerel işbirliğine daha yatkın olması ve iş güvencesine yönelik mevzuatlar, ülke ÇUŞ'larının çok daha sınırlı bir şekilde küresel stratejiler izlemesine olanak vermiştir (Lane, 1998). Buna karşılık SPE ÇUŞ'ları çok daha saldırgan ve coğrafi anlamda yayılmacı küresel stratejiler izleyebilmektedir. Orijin ülkedeki iş güvencesinin düşük olması ve finans kapitalin kısa dönemli karlar konusunda şir- 
ketler üzerinde kurduğu baskı, ÇUŞ’ların şirket operasyonlarının bir kısmını düşük maliyetlerin olduğu gelişmekte olan ülkelere kaydırmalarında daha teşvik edici olmaktadir.

Yine Alman şirketleri üzerinde çalışan Vitols (2004) artan uluslararası yatırımlar sonucunda Alman paydaş sisteminin ne ölçüde değiştiği üzerine bir inceleme yapmıştır. Araştırma sonuçlarına göre bu yatırımlar soncunda çoğalmiş ve çeşitlenmiş hissedar koalisyonlarının hisse payı değeri üzerindeki etkisi yadsınamayacak boyutlara ulaşmıştır. Alman şirketlerinde uluslararası muhasebe sistemlerinin (US_GAAP gibi) uygulanmaya başlaması değişimlerden biridir $^{5}$. Almanya gibi güçlü bir paydaş sistemine sahip bir ülke bile değişim baskısı yaşamaktadır. Bunun gerisinde birçok büyük şirkette küçük miktarda hisseye sahip, örneğin emeklilik ya da yat1rım fonu türünde, 'Anglo-Sakson' tipi hissedar temelli yönetişime yakın duran yatırımcılar yatmaktadır. Bu tip yatırımcıların şirketlerin hisse mülkiyetindeki payları giderek artmaktadır (Vitols, 2004). Bir bütün olarak ele alındığında değişimin iki düzeyde gerçekleştiğinden bahsedilmektedir. Kurumsal düzeyde kurumsal yatırımcıları içeren savaş sonrası (şirket yönetişimin de yöneticilerinin ve sendika temsilcilerinin beraberce yer aldığı) paydaş modelinden (kurumsal fonların görüşlerini de bu paydaşlar denklemine dâhil eden) çoğalan paydaş koalisyonlarına doğru bir değişiklik olduğu belirtilmektedir. Uygulama düzeyinde ise geleneksel paydaşlar ile fon yöneticileri arasında müzakere edilmiş hissedar değeri sisteminin ortaya çıktığını öne sürülmektedir.

Ancak uluslararası yatırımlar sonucunda ortaya çıkan tüm bu benzeştirici baskılara rağmen her iki seviyede de hissedarların 'Anglo-Sakson' sistemlerinde olduğu gibi alınacak kararlarda egemen bir aktör mertebe- sine ulaşamadığı vurgulanmaktadır. Dolay1sıla, Vitols'un (2004) getirdiği yoruma göre, Alman iş sisteminde belli değişiklikler gerçekleşse de, bunların yönü benzeşme/yakınsama- kapitalist çeşitliliğin yani ulus devletler arasındaki farklılıkların devam ettiğini savunan "şüpheci"- 1raksama savına destek vermektedir.

Benzer şekilde Whitley v.d.'nin (2001) tarihli çalışmasında, Japon firmalarındaki Japon ve İngiliz yöneticilerle görüşme yaparak bu değişimler incelenmektedir. Ülkedeki iç piyasanın zayıflaması ve Japonya'ya yönelik yabancı ilgisinin artması bir dizi Japon çok uluslu şirketlerin operasyonlarını yeniden değerlendirmesini gerektirmiştir. Özellikle Amerika olmak üzere farklı çalışma şekilleri ile beraber birkaç Japon firması zayıflamış ve bu durum Japon firmalarını yeniden yapılandırmaya yöneltmiştir. Ancak, çalışmanın sonucuna göre sınırlı bir değişim yaşanmakta ve birçok Japon firmaları açısından, alınacak uzun vadeli stratejik yönetim kararlarında, iç piyasadaki rekabetin hala çok önemli olduğunu göstermektedir. Görüşmelerde uluslararasılaşmanın etkisinin şirket stratejilerinde ve yapısındaki sınırlı olduğu belirtilmiştir. Özellikle de etnik merkezli kariyer politikalarıyla desteklenen yerel personelin, örgütsel denetim üzerindeki etkisi devam etmektedir.

Doksanlı yılların sonlarına doğru kurumsal yaklaşımların küreselleşmeyi yakınsamacı tezlerden ziyade iraksamacı bir kavrayışla ele aldığı söylenebilir. Bir sonraki bölümde değinileceği üzere dönüşümselci yaklaşımlar ise, bu iki zıt açılama çerçevesi arasındaki keskin salınımların ötesine geçmeye çabalamaktadir.

\section{DÖNÜSÜMSELCI KURUMSAL PERS- PEKTIFLER}

Giriș kısmında değinilen genel akademik küreselleşme tartışmalarındaki üçüncü yol

5 Karşılaştırmalı politik ekonomi çalışmaların da, şirket yönetișim sistemlerine ilișkin iki temel ayırım vardır. Bunlar hissedar ve paydaş sistemleridir. Hissedar sisteminde, hissedarlar şirketin hissedarlar değerlerini en çoklaştırmak üzere egemen çıkar gruplarıdır. Örneğin İngiltere ve ABD bu sisteme örnek verilebilir. Diğer taraftan paydaş sisteminde ise güç, hissedar ve diğer gruplar (örneğin çalışanlar) arasında paylaşılmıştır. Almanya ve Japonya bu çeşit bir sisteme örnek verilebilir. 
arayışlarına paralel olarak makro-kurumsal çözümleme yaklaşımını savunan bir kısım araştırmacı, küreselleşmenin yarattığı etkileri ıraksama/yakınsama dinamiklerini tek taraflı olarak ele alan açıklamalardan kaçınmaktadırlar. Söz konusu araştırmacılar, küreselleşmenin benzeşme ve ayrışma yönündeki eğilimlerinin beraberce ele alınmasıyla veya bu ikili baskının yarattığı melezleşme sentezinin çözümlenmesiyle anlaşılabileceğini öne sürmektedirler.

\subsection{Iraksama ve Yakınsama Desenlerini Bir- likte Ele Alan Çalışmalar}

Benzeşme ve ayrışma dinamiklerini beraberce ele alan çalışmalara baktığımızda yap1lan ampirik incelemelerin ağırlıklı olarak meslekler ve ÇUŞ’lar üzerinde yoğunlaştığını tespit etmekteyiz.

Örneğin, Lane v.d., (2000) profesyonelleşmeye aktarım süreçlerinin farklı sosyal ve ekonomik bağlamlarda nasıl geliştiğini incelemişlerdir. Çalışmada iki farklı Avrupa toplumundaki (İngiltere ve Almanya) iki mesleğe (avukat ve eczacı) odaklanılmıştır. Bu iki toplumun meslekler ve meslek sistemi açısından kurumsal parametreler, devlet, piyasa ve meslek gruplanmaları açısından belirgin bir biçimde farklı tarihsel yörüngeleri olduğu belirtilmiştir. Bu iki meslek grubundaki değişimlerin yönü aynı olmakla birlikte sonuçları belirgin bir biçimde farklılık göstermektedir. Araştırmacılar bu farklılıkları ortaya koyarken, toplumsal kuruluşların güçlü etkilerine bağlamak üzere farklı tarihsel gelişimlere ve farklı kurumsal çevreye (devlet, kuruluşlar, pazar, teknoloji) sahip ülkelerin nasıl farklılık yarattı̆̆ına odaklanmıştır. Çalışmanın sonucuna göre, küreselleşme ya da Avrupalaşma tartışmalarının bazılarında geçen yakınsamanın aksine, araştırmacılar süregelen bir ıraksamanın olduğunu savunmaktadır. Buna ek olarak çalışmanın bir diğer sonucuna göre, Almanya'da büyük ölçüdeki pazar müdahalelerine rağmen incelenen iki meslek de 'esnaf' (küçük zanaatkar) konumunu muhafaza etmekte olup ve bu mesleklerin mensupları İngiliz meslektaşlarına göre daha fazla toplumsal statüye sahiptir. Ancak, araştırmacılar ıraksamanın olduğunu söylerken yakınsama süreçlerini incelemeyi de ihmal etmemişlerdir. Seçilen bu farklı toplumlardaki farklı iki meslek sistemi günümüzde geçmişte olduğundan daha az farklılık göstermektedir. Bu tip bir yakınsama devletten gelen benzer ulusal baskilar ve müşteriler ya da avukat mesleğinde olduğu gibi uluslararası rekabetten kaynaklanıyor olabilir.

Harzing ve Sorge (2003) ana ülke etkileri ile evrensel koşulların çokulusluların uluslararasılaşmasındaki ağırlığını incelemektedir. Uluslararasılaşma iki tür etkinin sonucu olarak görülmektedir. Bunlardan birincisi, ana ülke dışındaki ülkeler ile kurulan bağlantılar ve bu ülkelerdeki müşteriler, tedarikçiler, ortaklar ve nispeten homojen yapıdaki düzenleyici kurumlar ile kurulan ilişkiler sonucu ortaya çıkan etkilerdir. Bu etkiler evrensel koşullar seti olarak kabul edilmektedir. İkinci tür etki ise rekabetçi baskılar ve düzenleyici normlardan kaynaklanmaktadır. Bu etkiler Avrupa Birliği ve Avrupa Ekonomik Bölgesi gibi daha dar bir kapsamda ele alınmaktadır. Söz konusu çalışma bu iki etki ekseninde çok ulusluların benzeşme ve ayrışma eğilimlerini incelemektedir. $\mathrm{Bu}$ eğilimler işletmelerin uluslararasılaşma stratejileri ve kurumsal kontrol mekanizmaları düzleminde ayrı ayrı ele alınmaktadır. Uluslararasılaşma stratejileri, çok ulusluların merkez ve şubeleri arasındaki bağlantılar ile ilişkileri nasıl yönettikleri bilgisini içermektedir. Kurumsal kontrol kavramı ise örgütsel denetimin ne ölçüde merkezileştiği, açıklı̆̆1 ve kişisellik düzeyi sergilediğini göstermektedir. Araştırmanın sonuçları, ana ülke etkilerinin özellikle çok uluslu işletmelerde kontrol mekanizmalarının biçimlenmesinde büyük bir ağırlığa sahip olduğu, uluslararasılaşma stratejilerinin belirlenmesinde ise endüstri ve işletme büyüklüğü gibi daha evrensel faktörlerin ağırlık kazandığı yönündedir. Bu durum aynı zamanda çok uluslu işletmelerde strateji ve örgütsel denetim unsurları arasında bağlantı olmadığını göstermektedir.

Bu sonuçlar, kanımızca, ayrışma ve benzeşme dinamiklerinin örgütler üzerinde farklı 
seviyelerde etkili olabileceğini yani bu ikili dinamiğin eşzamanlı olarak var olabileceğini göstermeleri açısından dikkate değerdir. Ancak aşağıdaki bölümde göreceğimiz üzere, dönüşümselci perspektifler bu duruma ek olarak, küreselleşmenin tetiklediği bu ikili baskının (ayrışma/benzeşme) sonucunda uluslararası ve yerel iş uygulamalarından bazılarının seçici olarak harmanlanması ile yaratıc1 sentezlerin oluştuğunu da gözlemlemektedirler.

\subsection{Melezleşme ve ÇUŞ'ların kurumsal çeşitliliği yönetebilme kapasitesi}

Uluslararası iş uygulamalarının benimsenmesi ile bunların yerel koşullara uyarlanması arasındaki diyalektiği otaya çıkaran "melez çözümler" açısından ele alan pek çok araştırma mevcuttur. Örneğin Höpner ve Jackson (2006) 2000 yılında Mannesman AG'nin Vodafone tarafindan 'düşmanca ele geçirme' (devralınan alınan şirket onaylamadığı halde hisse toplayarak iktisap) yapılarak devir alınması örnek olayını bu bağlamda incelemektedir. Milyarlarca dolarlık bu devir alınma olgusu dünya üzerinde 'Anglo-Sakson' finansal yönetişim uygulamalarını yayginlaştıran ve Vodafone'un yüksek halka açıklık oranlarında da kendini hissettiren uluslararası "hissedar" sermayesinin gücünü yansıtan önemli bir örnek olay teşkil etmektedir. Bir diğer deyişle bu örnekte İngiliz telekomünikasyon şirketi Vodafone'un getirdiği 'SPE tipi' küreselleşme etkilerinin Alman şirket yönetişimi üzerindeki tesirleri ele alınmıştır. Araştırmacılara göre böylesi bir durumda bile uluslararası yakınsamaya rastlanılmamaktadır. Ancak devir sonrasında Alman Mannesman'daki şirket yönetişimi eski biçimiyle muhafaza edilemediği için rraksamadan da bahsedilememektedir. Almanya'da bu ve benzeri şirketlere yurtdışı yatırımların artması yoluyla kademeli olarak ortaya çıkan şirket piyasası üzerindeki hissedar kontrolü, Alman şirket yönetişiminin gittikçe hem piyasa hem de piyasa-dışı unsurların ${ }^{6}$ karışımından bir niteliğe bürün- mesine yol açmaktadır. Bu yeni sistemde karar verme ve çıktıların müzakeresi açısından salt hissedar bakış açısıyla uyumlu Anglo-Amerikan paydaş sisteminden ayrışan belirgin farklılıklar oluşmaktadır. Dolayısıyla bu farklılaşma, eskinin devamı niteliğindeki bir rraksamacı etkiden ziyade, satın alınan Alman şirketinde ulusal kökenli iş yapma biçimleri ile uluslararası yaklaşımların sentezlendiği yeni bir yönetişim uygulamasına işaret eder. Serbest piyasa ekonomilerinin yönetişim uygulamalarının şirket muhasebesi alanında yarattığı şeffaflık baskıları, Alman sisteminin EPE niteliğine sahip olması sonucunda yönetimde yer alan sendikaların alınacak stratejik kararlarda daha fazla bilgi sahibi olmasını yol açarak bu paydaşların da pazarlık gücünü arttırabilmektedir (Höpner ve Jackson 2006).

Alman sistemindeki söz konusu melezleşme süreçlerine ilişkin değerlendirmeler yapan Lane (2003) Alman iş sistemi örneğini ele alarak, yukarıda farklı yorumlar eşliğinde ele aldığımız finansal sistem üzerindeki Anglo-Sakson kaynaklı etkilerin yarattığı, melezleşmenin istikrarsız yapısına dikkat çekmektedir. Lane (2003) bu tarz kurumsal dönüşümlerin birikimli niteliğine ve yerel aktörlerin çıkarları ile gücünün önemli olduğu görüşünü savunmaktadır. Ancak Lane (2003) aynı zamanda sistem içinde birbiri ile farklı kurumsal mantıkları destekleyen yerel ve uluslar arası çıkar grupları olacağı görüşünü de kabul etmektedir. Fakat, tam da bu noktada, melezleşme arayışlarının sürükleyicisi konumundaki bu parçalı dinamiğin sürdürülebilirliğini sorgulamaktadır. Lane'e (2003) göre küreselleşme ile yurtdışından ithal edilen 'yabanci' kurumsal mantıklar bazı eylemleri meşru, diğerlerini ise meşruiyetini azaltan hedef ve beklentileri de içermektedir. Bununla birlikte alıcı ülkedeki kurumlar, ithal edilebilecek bazı uygulamalara eşlik eden bu tarz amaçlara yönelik sınırlamalar getirmektedir. Bu nedenle de melezleşme çabalarının istikrarsız ve geçici olma tehlikesine işaret et-

\footnotetext{
6 Bir diğer deyişle hem hissedarların hem de sendikalar aracılığıyla temsil edilen şirket içi çalışanların yani firmadaki toplumsal paydaşların beraberce şekillendirdiği bir yönetişim yapısı.
} 
mektedir. Çünkü aktörler stratejik kararları, örneğin belli bir alanda piyasa mantığına göre, diğer alanda da bununla çelişen paydaş sisteminin mantığına göre almakta zorlanacaklardır. Lane (2003) finans sistemi gibi, ülkelerin iș sistemleri açısından merkezi öneme haiz, bir kurumda belli bir 'kurumsal mantık' doğrultusunda değişim söz konusu olduğunda tüm bir ulusal sistem içindeki ilişkileri yöneten mantığın da değiştiğini, bunun firmalar ve politik sistemin güçlü aktörleri tarafından destekleneceğini ileri sürmektedir. Çelişen farklı kurumsal çıkarların sonucunda bir tarafın ağırlığının artması sonucunda sentez arayışlarına gerek kalmayabilecektir. Melezleşme süreci ancak ve ancak iki farklı yönde baskı yapan güçlü aktörler tarafından desteklendiği takdirde sürdürülebilir bir niteliğe bürünecektir.

Son zamanlarda dönüşümselci bakış aç1sıyla geliştirilen kurumsal perspektifler Lane'in değindiği melez dönüşümlerdeki istikrarsızlaştırıcı eğilimlere paralellik arz eden diğer bir benzer temaya değinmektedir.

$\mathrm{Bu}$ bağlamda küreselleşmenin ve çok uluslu şirketlerin yarattığı iktisadi baskılar sonucunda ülkeler içinde güçlenen 'kurumsal farklılaşma' etkisi de incelenmeye başlanmıştır. Burada farklılaşma ile kast edilen ÇUŞ’ların yatırım yaptıkları ülkede, hakim kurumsal düzenlemeleri dişlayarak ve bu düzenlemeleri destekleyen baskın iş gruplarının dışındaki aktörlerle koalisyonlara girerek, yarattıkları "kurumsal çeşitlenme" etkisidir. Burada, statik bir rraksama (ulusal farklılıkların çok büyük değişime uğratılmadan muhafaza edilmesi örneği) veya yakınsamaya (Amerikanlaşma tarzı hakimiyet etkilerine pasif uyum gösterme örneğinde olduğu gibi) dayalı çözümleme çerçevesinin dışına çıkılmaktadır. ÇUŞ'ların ana ülke ile misafir ülke iş sistemleriyle olan ilişkilerini beraberce kavramsallaştıran ve kurumsal yapılar içindeki farklı toplumsal çıkar gruplarının oluşturduğu fay hatlarına odaklanan parçalı ve dinamik bir çözümleyici çerçeve söz konusudur.

Bu bağlamda ilk olarak ele alacağımız bir grup araştırmacı (Hanckle et al., 2007, Morgan et al., 2005; Streeck ve Thelen 2005; Whitley, 2007) iş sistemlerinin yekpare bir şekilde ele alınması yerine bunlardaki içsel farklılaşmaya odaklanmaya başlamıştır. Buna göre bir iş sistemini ülke içinde başat konumdaki EPE veya SPE niteliklerine referansla tanımlamak yeterli olmamaktadır. Çünkü bu yapılar içerisinde mevcut ulusal/kurumsal mimariden farklı şekillerde etkilenen toplumsal çıkar koalisyonları mevcuttur. Bazı sektörler ve firma grupları baskın genel kurumsal mimariyle uyumlu ve iç içe geçmiş bir yapı sergilemekte iken, diğer sektör ve gruplar kendilerini yeterince desteklemeyen hakim kurumsal düzenlemelerin dışındaki çözümlere yönelmektedirler. Küreselleşme süreci ile beraber ulusal sistemlerde bu türden farklılaşmayı büyük ölçüde etkileyen, genel olarak çok uluslu şirketlerin gelişimidir. Bu durumda yanıtlanmayı bekleyen bazı sorular ortaya çıkmaktadır. Bu örgütler ulusal sistemlerde daha mı fazla içsel farklılaşmaya yol açmaktadır? Ya da farklılaşmayı daha mı azaltmaktadırlar? Böylelikle Morgan'a (2010) göre cevabı aranması gereken soru, çok uluslu şirketlerin ülkelerin kurumsal mimarisi üzerinde yarattığı etkiden ziyade bunların içsel çeşitlenme yapıları ile olan etkileşimleri olmalıdır. Morgan (2010) bu etkileşimleri EPE ve SPE dikotomosini zenginleştiren bir yaklaşımla ele almaktadır. Burada, EPE'lerinin ulusal ölçekte üç alt başlıkta detaylandırılması ve farklı iş sistemlerindeki içsel konfigürasyonların çeşitliliğinin çözümleme sürecine dahil edilmesi yoluyla, kurumsal çeşitlenmenin çok uluslu şirketlerin ve küreselleşmenin etkisiyle nasıl bir dönüşüme uğradığı meselesine odaklanılmaktadır. Bu etkileşimler dört farklı sistemin incelenmesiyle ele alınmaktadır (bkz. Morgan 2010; Whitley, 2007)

1- Liberal piyasa sistemi: Bu tip ekonomiler düzenleyici devletleri içermektedir. Genellikle bu ekonomiler, ekonomik faaliyetlere veya sektörlere doğrudan müdahele etmek yerine bunların genel çerçevesini belirleyen kuralları koymaya odaklanmıştır (örneğin 
piyasada rekabetin sağlanmasına yönelik tüm sektörleri eşit derecede ilgilendiren yatay düzenlemeler). Bununla beraber diğer alanlarda güçlü bir müdahaleci yanları vardır. Genelde güçlü kurumsal tasarım süreçlerine yönelmezler, çünkü aktörler tek bir merkezden yönetilmemektedir (decentralized) ve genel olarak pazar değişimlerine çabuk tepki verebilmek için özerk kalmay1 tercih ederler. Morgan'a (2010) göre bu gevşek kurumsal yapılar diş etkilerin nüfuz etmesine, yani farklı ülke ÇUŞ'larının kendi kurumsal mantıklarını ve bunun uzantısı olan iș uygulamalarını aktarmasına, elverişli bir çerçeve sunarlar.

2- Kapsayıcı dayanışmacı (inclusive corporatist) sistem: Güçlü çıkar gruplarını (devlet, sendikalar, büyük şirket birlikleri, ticaret ve sanayi odaları gibi) temsil eder. Bunlar genelde maaş, vergi, çalışma koşulları, beceri ve ödüllendirme gibi konularda standartlaşma yaratırlar. $\mathrm{Bu}$ nedenle bu sistemlerde kurumsal farklılık düzeyi düşük olur. Ağırlıklı olarak İskandinav ekonomilerinin ve Almanya'nın temsil edildiği bu sistemde, ÇUŞ'ların, dayanışmacı toplumsal sistemin yerel aktörleri arasındaki sıkı çıkar işbirliğine ve bilgi paylaşımina dayalı olarak gelişen özel sektör yetkinliklerine nüfuz ederek buradaki stratejik varlıklara erişimi sağlaması zor olacaktır. Yine de bu tip ülkelerde imalat sanayinin daha dışa kapalı bir yapı arz ettiği, hizmet sektöründe ise görece uluslararasılaşma etkilerine daha açık bir yapı olabileceği vurgulanmaktadır.

3- Özel sektör temelli dayanışmacı (business corporatist) sistem: $\mathrm{Bu}$ sistemlerde egemen aktörler devlet ve büyük işletmelerdir. Bu büyük işletmeler belirli ilişkiler doğrultusunda doğrudan devlete bağlıdır. Bu sistemlerde büyük şirketler ile yönettikleri ticari ilişki ağları (tedarikçi ve müşterilerle olan ilişkiler gibi) etrafında kurgulanan şirket topluluklarının birbirleri arasındaki parçalı yapı (segmanter yapı) devlet ta- rafından desteklenmektedir. Bu sistemler sınırlı da olsa belli ölçülerde içsel farklılaşma biçimine sahiptir fakat doğasında sinırlama vardır. Japonya bu sisteme örnek verilebilir.

4- Kalkınmacı devlet sistemi: Kalkınmacı devletler, iş ve işçi ile ilgili güçlü aracı birliklerin ortaya çıkmasını desteklemez. Bunun yerine bu tip sistemler, genel olarak devletin sanayi politikaları güdümünde kalarak belirgin şirketlere ve sektörlere teşvik yoluyla ağırlık vererek uluslararası rekabetçi kapasitelerini yönetmeye gayret ederler. Bu şirketler genel olarak devletin sağladığ korumacı bir kurumsal çevrede seri üretime odaklanırlar. Bu sistemlere örnek olarak Güney Kore, Malezya, Endonezya, ve Tayvan verilebilir. Morgan (2010) özel sektör ve kalkınmacı devlet modellerinde sektör temelli içsel farkl1laşmadan ziyade, toplumsal aktörler arasındaki güç dağılımıyla ilişkili çeşitlenme olabileceğine işaret etmektedir. Özellikle kalkınmacı devletlerde büyük iş gruplarını kollayan devlet sisteminin dışladığ 1 küçük girişimcilerin, ÇUŞ’lar ile koalisyona yönelerek, geleneksel bürokrat/holding dayanışmasına alternatif yaratma girişimlerine yönelmesi mümkündür.

ÇUS'ların iş sistemleri ile dinamik etkileşimlerini ele alan ikinci bir perspektif ise bunların orijin ülkesi ile yurtdıșı yatırımlarının yöneldiği ülkeler arasındaki kurumsal farklılıkları ele almaktadır. Bu yaklaşımda söz konusu farklılıklar ÇUŞ'ların uluslararasılaşma sınırlarının belirlenmesinde kritik öneme haizdir. Aşağıda gösterileceği üzere bu sınırlar iki açıdan ele alınmaktadır: (a) şirketin mülkiyet alanını yurtdışında yatırımlar yoluyla genişletme kapasitesi (b) orijin ülkedeki üretim sistemlerinin alıcı ülkeye benimsetilebilme derecesi. Kristensen ve Morgan'ın (2007) meseleyi çok ulusluların kurumsal rekabet gücü çerçevesinde incelemeyi amaçlayan çalışmasında çok ulusluları kısa ve uzun dönem odaklılık bakımından, kurumsal rekabet gücünü ise tamamlayıc1- 
lık ve içsel bağlantıların güçlü ya da zayıf olması bakımından ikiye ayırmaktadır. Böylece çok uluslu şirketler ve kurumsal alan arasındaki farklı etkileşim olasılıkları incelenmektedir. Daha sonra her bir etkileşim türünün kurumsal rekabet gücü üzerindeki etkisi analiz edilmektedir.

Ulus ötesi şirketler ilk olarak ortaya çıtıkları orijin ülkedeki yerel kurumsal koşullarla etkileşimleri bakımından uzun dönem odaklı ve kısa dönem odaklı olmak üzere ikili bir ayrıma tabi tutulmaktadır. Uzun ve kısa dönem odaklılık; üst düzey yöneticilerin sermaye piyasaları, mülkiyet hakkı sahipleri ve diğer çıkar grupları ile ilişkileri tarafından belirlenmektedir. Merkezi ABD ve Birleşik Krallık olan çok uluslular, orijin ülkenin daha önce değinilen SPE şirket yönetişimdeki baskın hissedar nitelikleriyle uyumlu olarak, kısa dönem odaklı olarak s1nıflandırılmıştır. İskandinav ve Japonya (EPE) merkezli çok uluslular uzun dönem odaklı olarak sinıflandırılırken, Alman çok uluslu şirketleri bu iki kategori arasında kalmaktadir.

Çok ulusluların şubelerinin içinde bulunduğu yerel kurumsal koşullar da iki kategoride ele alınmaktadır. Bir yanda aktörlerin birbirine sıkıca bağlı olduğu, dayanışma ve güvene dayalı ticari ilişki ikliminin işlem maliyetlerini düşürerek piyasayı düzenlediği güçlü kurumsal tamamlayıcılıklardan oluşan kurumsal rekabet ortamı söz konusudur. Diğer yanda ise bunun tersini ifade eden zayıf kurumsal rekabet gücü olan ülkeler söz konusudur.

Güçlü yerel kurumlar ile uzun dönem odaklı çok ulusluların bir araya gelmesi durumunda yabancı sermayenin iç piyasaya girmesi ve yeni iş sistemlerini uygulamaya sokma girişimleri yerel unsurların direnciyle karşılaşacaktır. Güç ve politik taktiklerin hakim olduğu uzun bir uzlaşma süreci sonucunda piyasaya giren çok ulusluların kurumsal koşullar üzerinde etkili olması beklenmemektedir. Bu duruma Finlandiya merkezli çok uluslu bir işletmenin Almanya şubesinin yeni uygulamalara dirençle karşı- lık vermesi örnek gösterilebilir. (Geppert v.d. et al. 2002).

Öte yandan kurumlar arasında düşük entegrasyon ve zayıf bağlar olması, değişim ve gelişim için fırsat sunmakla beraber, özellikle işgücü piyasasında ortaya çıkan ve finansal piyasalar tarafından da pekiştirilen kısa dönemlilik ve fırsatçılığa ortam hazırlayacaktır. Böyle bir kurumsal ortam hem piyasaya girişin kolay olması hem de dişsal etkilere açıklık bakımından esneklik sunması bakımından çok uluslular tarafından tercih edilecektir. Uzun dönem odaklı firmaların, mevcut kurumların zayıf ve bölünmüş olduğu bu tür piyasalarda yerel kurumsal yetkinlikleri yenilediği ve geliştirdiği görülmektedir. Bu duruma örnek olarak Japon otomotiv üreticilerinin girişiyle İngiliz otomotiv endüstrisinin kalite, beceri ve yenilik bakımından ilerleme kaydetmesi gösterilebilir (Oliver ve Wilkinson 1992).

$\mathrm{Bu}$ noktada elde edilen sonuçlar bize ÇUŞ’ların misafir ülkenin kurumsal mimarisi üzerinde yekpare bir dönüştürücü sonuç getirmesinden ziyade farklı toplumsal aktör koalisyonları ve farklı kurumsal bağlamlarda çeşitlenen "parçalı" etkiler yaratmasının olası bir sonuç olduğunu göstermektedir. Bu bağlamda Gültekin-Karakaş'ın (2009) Türkiye'deki banka sahibi holdinglerin 2001 krizi sonrasındaki küreselleşme çabalarında devletin, bir aktör olarak, önemli bir rolü olduğu vurgusu makro-kurumsal çalışmaların yeterince dikkate almadığı önemli bir tespittir. Ancak burada da kurumsal yazının, Gültekin-Karakaş'ın (2009) ulus-temelli ve/veya uluslararası ölçekteki farklı sermaye fraksiyonlarının talepleri arasında arabulucu rolünde konumlandırdığı, devletin hareket alanını belirleyebilecek parametrelere işaret ettiği belirtilmelidir. Sıkı içsel kurumsal bağlantıların ve bunlarla iç içe geçmiş toplumsal çıkar koalisyonlarının mevcut olduğu ülkelerde devletin uluslararası sermaye fraksiyonları ile arabuluculuk yapabilme kapasitesi de sinırlanacaktır. 


\section{SONUÇ}

Makro kurumsal yaklaşımının küreselleşme tartışmalarına yaptığ 1 katkıları ve s1nırlılıklarını ele alacak olursak şu tespitleri yapmak mümkündür. Söz konusu yazının dünya ekonomisindeki bütünleşme eğilimlerini çözümlerken iki temel konu etrafında değerlendirme getirdiği ileri sürülebilir: Bunlar; uluslararası işletmecilik faaliyetleri ile "en iyi işletmecilik" uygulamalarının yayilımidir.

İlk olarak makro kurumsal yaklaşımın uluslararası işletmecilik çerçevesinde yaptığı katkıları ele alalım. Bu bağlamda ana akım uluslararası işletmecilik kuramı açısından ÇUŞ’lar üzerindeki ulusal etkiler,sadece maliyetler veya kültürel etkiler bağlamında ele alınırken, özellikle şüpheci kurumsal kuram ÇUŞ'ların ulusal aidiyetini inceleyerek bunların rekabetçiliklerini etkileyen kurumsal (dolayisiyla da toplumsal ve siyasi) saiklerin en detaylı listesini oluşturmuştur. Burada bu kurumsal faktörlerin sinıfland1rılması ile de yetinilmemiş, bunların arasındaki içsel bağlantıların incelenmesi yoluyla tamamlayıcılıkların, yani nedensellik dinamiklerinin, çözümlemeye dahil edildiği kavramsal kuramsal bir çerçeve oluşturulmuştur. Özellikle ÇUŞ’ların farklı ülkelerin toplumsal formasyonunu nasıl etkilediği, firmaların kullandığ 1 girdilerin (emek ve sermaye gibi) coğrafya tarafından nasıl şekillendiği gösterilmektedir. Böylelikle tamamlayıcılıkların ÇUŞ’lar üzerinde iki farklı eksende belirleyici olduğu ortaya konulmaktadır. Ulusal etkiler bir yönüyle şirketlerin uluslararası rekabette kullanacakları çekirdek kabiliyetlerinin temelini oluşturmaktadır, diğer yönüyle de uluslararasılaşmanın sınırlarını belirlemektedirler.

Örneğin SPE bağlamında ortaya çıkan ÇUŞ'ların daha radikal yeniliklere yönelmesi ve yurtdışı yatırımlarında daha saldırgan bir yap1 arz etmesi beklenebilir. Küreselleşmeyi yakınsamacı bir bakış aç1sıyla değerlendiren makro kurumsal çalışmalar ÇUŞ’ların kurguladığı ulus ötesi örgütsel uzamin milletler üstü niteliğinin tam da yukarıda değinilen ulusal farklılıklar arasındaki "kurumsal arbitraj" imkanlarının kullanılmasıyla oluştuğunu vurgulamaktadırlar. Sonuç olarak birbirine zıt bir şekilde konumlanan makro kurumsal yazının küreselleşmeci ve şüpheci versiyonları ulus devletin ÇUŞ’lar üzerindeki etkisini çözümlemelerinin odak noktasına yerleştirmişlerdir. Burada dönüşümselci bakış açıs1nın ÇUŞ'ları ağırlıklı olarak orijin ülkenin getirdiği koşullanmalar çerçevesinde ele alan yaklaşımlara ek olarak, yatırım yapılacak ülkedeki kurumsal düzenlemelere dikkat çekmiş olması önemlidir. Gerçekten de bu şirketlerin yurtdışındaki yatırım performansı, en az sahip oldukları ana ülke güdümlü kabiliyetler kadar, misafir ülkedeki sıkı veya gevşek içsel bağlantılar yoluyla şekillenen tamamlayıcılıkların sunduğu sızdırganlık derecesine bağlıdır.

İkinci olarak, kurumsal kuramin -hakimiyet etkileri olarak da nitelenen- iş modellerinin uluslararası yayılımı alanındaki katkıları söz konusudur. Bu yaklaşımın da başlangıçta, küreselleşme tartışmalarında olduğu gibi, yakınsama-ıraksama ikilemine s1kıştığını görmekteyiz. Kapitalizmin coğrafi çeşitliliğine dikkat çeken bir yaklaşımın özellikle küreselleşme çağında tek tipleşmeye direnen farklı iş yapma biçimlerine vurgu yapması doğal iken yine aynı yazın içinde yakınsamanın kurumsal koşullarına dair açıklamalar getirilmesi de, ilk bakışta paradoksal gözükmekle beraber, küreselleşmenin farklı veçhelerine dikkat çekmesi açsından faydalıdır.

Küreselleşmenin yakınsamacı etkileri incelenirken yurtdışından ithal edilen (Japon, Amerikan vb.) işletmecilik modellerinin mutlak teknik üstünlüğe sahip modellerden ziyade içinde bulundukları kurumsal çerçeveye gömülü iş uygulamaları olduğuna dikkat çekilmektedir. $\mathrm{Bu}$ modellerin uluslararası iktidar ilişkilerinin sonucunda ve çelişkili/kırılgan bir kurumsal çerçeve içinde şekillendiğinin ortaya konulması sürdürülebilirlik meselesini gündeme getirmektedir. Bu da "en iyi işletmecilik" uygulamaları etrafında oluşan teknik ve 
mutlak sınai üstünlük iddialarını, özellikle gelişmekte olan ülkeler açısından, daha gerçekçi bir zeminde tartışma imkanı sağlamaktadir. Aslında, yakınsamanin -başlangıçta yerelde şekillenen- kırılgan kurumsal koşullarına dikkat çekilmesi, kanımızca, uluslararası alanda son küresel mali krizde tecrübe ettiğimiz gibi, ulus ötesi bir yapılanmanın ortaya çıkması için geliştirilmesi gereken kurumsal altyapının zorluğuna gönderme yapmaktadir. Küreselleşmeden ziyade iraksamacı etkileri savunan kurumsal görüşler de belli bir iş modelinin alıcı ülkeye transfer edilmesinde yöneticilerin ve politikacıların kendi ülkelerindeki kurumsal mimariyi, bu alandaki düzenlemeleri ve içsel tutarlığ 1 göz önüne almaları gerektiğini ortaya koyarak bütünleşmiş bir dünya ekonomisinin ortaya çımasının önündeki engelleri farklı bir açıdan göstermektedir. Yakınsamacı ve ıraksamacı kurumsal görüşler, birbirine zıt eğilimleri (benzeşme ve farklılaşma) gözlemlemelerine rağmen, gerçek manada küresel bir ekonominin oluşması için gidilecek mesafenin hayli uzun olduğu konusunda -farklı sebeplerle- görüş birliği içindedir.

Dönüşümselci yazının katkısı da bu bağlamda sadece iraksama ve yakınsama dinamiklerinin

bir arada ele alınmasıyla sınırlı görülmemelidir. Son dönem yazının ele aldığ 1 melez desenler, ağırlıklı olarak ulusal ölçekte şekillenen kapitalist çeşitliliğin ve onun uzantısı olarak gelişen iş modellerinin yoğrulabilirliği ve dışsal/küresel etkiler bağlamında esnekliğine yaptığ 1 vurguyla öne çıkmaktadır. Ayrıca ülkeler arası aktarım süreçleri sonucu dolaşıma giren iş modellerinin alıcı ülkelerde yaratacağ ${ }_{1}$ etkilere ilişkin önemli ipuçları getirilmektedir. Buna göre, bir işletmecilik uygulaması ortaya çıktığı orijin ülkeyle benzerlik arz eden bir iş sistemi aktörleri tarafından içsel kılınmaya çalışıldığında ulusal sınırların daha geçirgen bir yapı arz etmesi, iş sistemleri arasındaki kurumsal mesafe arttıkça da "tercümenin" zorlaşması beklenmektedir. Buna ek olarak makro kurumsal yazının, küreselleşmenin belirli bir iş sistemindeki farklı çıkar koalisyonları üzerinde değişik seviyelerde (uluslararasılaşma stratejisi, insan kaynakları uygulaması vb.) çok çeşitli etkiler (yakınsama/ıraksama/melezleşme) yaratabileceğini gösterdiği ileri sürülebilir. Bu tespitten yola çıkarak, küreselleşmenin etkilerinin, bu tarz çok katmanlı/çok boyutlu bir kavramsal/kuramsal çerçevenin geliştirilmesi ile açıklanması kanımızca daha bütüncül bir araştırma metodolojisine imkan verebilecektir. Bu da dünya ekonomisindeki bütünleşmenin getirdiği iktisadi baskılarla yüzleşen uygulamacılar aç1sindan olanaklar ve kisitların daha iyi kavranabilmesine firsat tanıyabilir.

ÇUŞ’ların farklı ülkelerin farklı kurumsal düzenlemelerini kullanarak yeni bir ulus ötesi mekan tasarladıklarını gösteren çalışmalar ve mikro düzeyde yeni oluşmakta olan bu uzam içerisindeki aktörler arasındaki karmaşı/kçok katmanlı etkileşimler 2010'lu yıllarda yazının yöneldiği yeni güzergahlar açısından fikir verebilir. Ancak ağırlıklı olarak arz taraflı açıklamalara yönelen, devletin rolünü yeterince kuramsallaştırmayan, çoğunlukla da örnek olay ve imalat sanayi verilerine dayanan bu çalışmaların sinırlılıklarını tespit etmek söz konusu yazının belli ölçülerde genelleştirilebilirlik sorunu taşıdığını vurgulamak açısından önemlidir. 


\section{Kaynaklar}

Aglietta, M. ve Breton, R. (2001), Financial systems, corporate control and capital accumulation, Economy and Society, $30(4), 433-$

466.doi:10.1080/03085140120089054

Amable, B. (2000), Institutional Complementarity and Diversity of Social Systems of Innovation and Production, Review of International Political Economy, 7(4), 645-687.

Amable, B ve Petit, P. (2001), The Diversity of Social Systems of Innovation and Production during the 1990's, Working Paper, Cepremap 2001/15.

Casper, S. ve Whitley, R. (2002), Managing competences in entrepreneurial technology firms: a comparative institutional analysis of Germany, Sweden and the UK. Proceedings of Takeda Foundation Symposium on Engineering Intellect and Knowledge, Scasss, Uppsala, June.

Chandler, A. (1990), Scale and Scope: The Dynamics of Industrial Capitalism, Cambridge, Harvard University Press.

Djelic, M. L. (1998) Exporting the American Model: The postwar transformation of European Business, Oxford, Oxford University Press.

Frenkel, M. ve Shenhav, Y. (2003),From Americanization To Colonization: The Diffusion of Productivity Models Revisted, Organization Studies, 24, 15371561.

doi:10.1177/0170840603249006

Geppert, M, Matten, D., ve Williams, K. (2002) Challenges for European Management in a Global Context, London, Palgrave.
Guillen, M. F. (1994), Models of management: Work authority, and organization in comparative perspective, Chicago CA, The University of Chicago Press.

Gültekin-Karakaş, D. (2009) Hem Hasımız Hem Hisımız: Türkiye Finans Kapitalinin Dönüşümü ve Banka Reformu, İstanbul, İletişim Yayınları.

Hall, P. A. ve Soskice D. (2001),Varieties of Capitalism. The Institutional Foundations of Comparative Advantage, Oxford / New York, Oxford University Press.

Hanckle, B., Rhodes, M. ve Thatcher, M. (2007), Beyond varieties of capitalism, Oxford, Oxford University Press.

Harvey, D. (1994), The condition of post modernity, England, Blackwell.

Harzing, W. A. ve Sorge A. (2003), The relative impact of Country of Origin and Universal Contingencies of Internalization Strategies and Corporate Control in the Multinational Enterprices: Worldeide and European Perspectives, Organization Studies, 24, 187-214. doi: $10.1177 / 0170840603024002343$

Held, D. McGrew, A. Gollblatt, D., ve Perraton, J. (1999), Global Transformations, Standford CA, Standford University Press.

Hirst, P. ve Thompson. (1996), Globalization in Question, London Polity Press.

Höpner, M. ve Jackson, G. (2006), Revisiting the Mannemann takeover: how markets for corporate control emerge, European Management Review, 3,142155. doi:10.1057/palgrave.emr.1500061

Kenichi, O. (1995), The End of the Nation State, London, Harper Collins Press. 
Kipping, M. ve Bjaenar, O. (1998),The Americanization of European business: The Marshall Plan and the transformation of management models, London, Routledge.

Kogut, B. (2008), Knowledge, Options and Institutions, Oxford, Oxford University Press.

Kristensen, P. H. ve Morgan G. (2007), Multinationals and Institutional Competitiveness, Regulation \& Governance, 1 , 197-212.

Lane, C. (1998), European companies between globalization and localization: a comparison of internationalization strategies of British and German MNCs, Economy and Society, 27,517540 .

doi:10.1080/03085149800000030

Lane, C. (2003), Changes in Corporate Governance of German Corporations: Convergence to Anglo-American Model?, Compettion and Change, 7,79-100.

doi:10.1080/1024529032000146678

Lane, C., Potton, M., ve Littek, W. (2000), The Professions Between State and Market A cross national study of convergence and divergence, ESRC Centre for Business Research, Cambridge, University of Cambridge Working Paper, No: 189.

Maurice, M., Sellier, F., ve Silvestre, J. (1982), Politique d'éducation et organisation industrielle en France et en Allemagne. Essai d'analyse sociétale,Paris, Presses Universitaires de France.

Morgan, G. (2001), Transnational communities and business systems, Global Networks, 1 (2), 113-130. doi:10.1111/1471-0374.00008
Morgan, G. (2010), Globalization, multinationals and institutional diversity, Economy and Society, 38,580-605. doi:10.1080/03085140903190342

Morgan, G., Whitley, R., ve Moen, E. (2005) Changing Capitalisms, Internationalization, Institutional Change and systems of economic organization, Oxford, Oxford University Press.

Oliver, N. ve Wilkinson, B. (1992), The Japanisation of British Industry: Developments in the 1990s, Oxford, Blackwell.

Özen, Ş. ve Berkman, Ü. (2007), Cross-national Reconstruction of Managerial Practises: TQM in Turkey, Organization Studies, 28, 825-851. doi:10.1177/0170840607079863

Smith, C. ve Meiskin, P. (1995), System, Society, and Dominance Effects in CrossNational Organisational Analysis, Work, Employment and Society, 9 (2),241-67.

Strang, D. ve Meyer, J. (1993), Institutional Conditions for Diffusion, Theory and Society, 22,487-511. doi:10.1007/BF00993595

Streeck, W. ve Kathleen, T. (2005), Beyond Continuity: Institutional Change in Advanced Political Economies, Oxford, Oxford University Press.

Üsdiken, B. (2009), Bir Örgütsel Alanın Yeniden Şekillenişi: Türkiye'de İş Hayatına Yönelik Yüksek Öğretimde Değişim 1955-1975, Ankara, ODTÜ Gelişme Dergisi., 35 (Özel Sayı),1-40.

Vitols, S. (2004), Continuity and change: Making Sense of the German Model. Competition and Change, 8,331-337. doi:10.1080/1024529042000304383

Waters, M. (1995) Globalization, Routledge, New York 
Westney, E. D. (1987), .Imitation and innovation: The transfer of western organizational patterns to Meiji Japan, Cambridge, MA, Harvard University Press.

Whitley, R. (1999), Divergent capitalisms: the social structuring and change of business Systems, Oxford, Oxford University Press.

Whitley, R. (2000), National Capitalisms, Global Competition and Economic Performance, Amsterdam, John Benjamins.

Whitley, R. (2003), How National are Business Systems The Role of States and Complementary Institutions in Standardising Systems of Economic Co-ordination and Control at the National Level, in Changing Capitalisms, Eds. Morgan, G. et al., pp.190-231.

Whitley, R. (2007), Business Systems and Organizational Capabilities: The institutional structuring of competitive competences, Oxford, Oxford University Press.

Whitley, R., Morgan G., Kelly, W., ve Sharpe, D. (2001), The Changing Japanese Multinational Consequences of Internationalisation and recession in manufacturing and financial services, Working Paper, 435. 